\title{
Interview with Dr. Viraj Mane: Manager at Ontario Genomics
}

\author{
By Pedrum Mohammadi-Shemirani
}

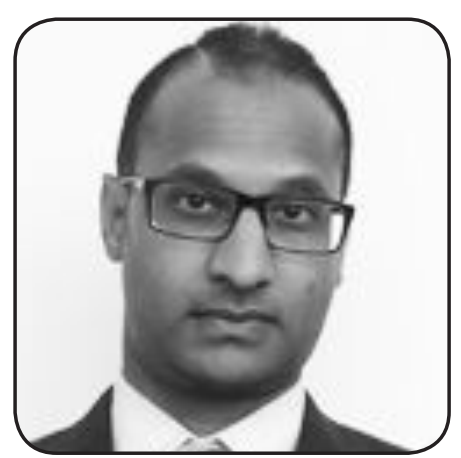

Dr. Viraj Mane is a Manager for Business Development \& Research at Ontario Genomics (OG), where he focuses on their water \& forestry portfolios. He received his PhD in Human \& Molecular Genetics from Baylor College of Medicine. After graduating, he went on to secure post-doctoral positions in immunobiochemistry and nanotechnology. After realizing academia might not be for him, he transitioned into the private sector, where he worked as a technical analyst for the United States Department of Defense. Upon relocating to Toronto, he initially secured a position at the MaRS Innovation Office focusing on technology commercialization for discoveries coming out of hospitals \& universities. He was then connected to his current position at OG, where he is more focused on project management and business development. He is primarily responsible for presenting the OG mandate to businesses that are looking for solutions but unfamiliar with genomics. He facilitates mutually beneficial partnerships among academic researchers, businesses, and end users; identifies sources of project funding; and provides consulting services to enhance clients' products using genomic tools.

Simultaneously, Dr. Mane has been designing and developing a diagnostic medical device. Beginning with independent research, he came up with an idea, reviewed literature, searched patents, applied for grants, and created a prototype on his own time and money. He was eventually able to partner with a hematology director at the children's hospital in Washington, $D C$ to conduct validation studies of the device. Ultimately, after rounds of patent rejections and appeals, this multi-year process has resulted in an issued patent for his invention.

\section{How did your graduate education prepare you for your career?}

I always tell graduate students when applying for non-academic jobs that it's not too important to dwell on specific techniques you've learned, since anyone can be taught a technique. You need to emphasize your other abilities, like a commitment to delving into the details of a project while still thinking about the problem at a high level. For instance, if your research is looking at a particular molecular pathway, you should still be thinking about its role in disease, the healthcare costs of the disease, quality of life for patients, and so on.

At the same time, even though I haven't been required to learn specific lab techniques in my current role, it is still vital that I understand them since I'm often interfacing with scientists. However, even if you may not have worked directly with a technique or technology, your knowledge of basic jargon will enable you to read the literature and come up to speed much faster.

Similarly, processing information effectively is one of the best skills PhDs can claim to have. You may not be able to remember details about everything, but you should know how to access information efficiently. Through your vast experiences appraising evidence in science, you will likely know how to sift through different sources, pick the best ones, and synthesize your findings accordingly to inform your experiments. These are the same skills used in strategic planning and project management. You might not know exactly how to make a project succeed, but you maximize your chances of success by collecting the best information to make the most informed decision. 


\section{What is your average day/week like? Can you describe a current project you are working on?}

There is a lot of variation from day-to-day, or even week-to-week, which is an aspect I enjoy a lot. But there are general activities that I'm often working on:

I reach out to companies, whom I have sometimes only spoken to briefly, so they can better understand the OG mandate and what we might be able to do for them. Or, I might be helping other companies that have already expressed interest move to the next steps. This involves brainstorming ideas to see what their next 6-12 months might look like, and, if all goes well, how we might leverage that into a multi-year project to benefit them.

We often look for different funding opportunities to put together joint projects for companies and academic researchers who may have never otherwise partnered. As an extension, we help administer larger-scale multiyear research grants through Genome Canada (a parent organization to $O G$ ) as well.

One of my proudest accomplishments has been getting the Ministry of Environment and Climate Change to understand our mandate better and to engage with us more, which may also lead to a new joint research project. I want to have an open dialogue with them, so we can ask them questions regarding environmental regulations or approvals. This allows us to deliver high-quality answers and solutions to our clients, which helps them adjust their development strategy and time frames. It's not easy for businesses to get feedback like that, so this is a value proposition that we can now start providing to our clients.

One example of our partnerships was investigating tools to improve the surface area for beneficial bacteria to grow in wastewater, so they can provide natural filtration functions. This biological treatment alternative is particularly useful for remote communities that can't afford mechanical treatment plants or chemically treated water. We secured some of our own funds for this project as well as three external sources, and it has been doing well so far. A more recent project involved a team that wanted to develop DNA reagents (aptamers) to detect pathogenic oocysts in water to determine whether it is potable or needs to be treated.

\section{What is your favourite and least favourite part about the job?}

My favourite is the diversity of tasks. We can't control which companies might find us, so they can range from established businesses to small companies or even startups. As a result, we use a common set of tools but we're always being asked to do different things. The variability means we are applying our skillset differently based on a client's background and particular goals.

I also like that management is encouraging of professional growth and taking initiative. They've given me more freedom compared to previous positions, and I really appreciate that they've put that trust in me.

The downsides are limited compared to other positions l've had. One of my earlier positions had a lot of reporting requirements, so I ended up spending a significant portion of time capturing all my activities into weekly and monthly reports. There is a bit of administrative work in every job, since all organizations need to keep records, but there is not as much of it at OG in my experience.

\section{What is the current demand for MSc or PhD students in your field?}

At OG, I believe all the other managers have PhDs. In fact, over half of our office has a PhD. It might not be a requirement, but it is definitely noticed by our board and our partners that the due diligence and level of review we provide is thorough and unique. We are a team of scientists who transitioned into more business-oriented roles but still have that analytical rigor earned from our previous education.

In terms of the larger industry, it depends on the specific area. In the innovation ecosystem, like many offices in the MaRS tower, there are a lot of MSc and PhD students. This is because you have to understand the technology to know if it is truly innovative or just duplicative of existing technologies. A scientist might approach you believing their invention to be an improvement, but you now have to read highly technical patents to be able to evaluate the technical and commercial merits of their claim at a deeper level.

With that being said, you must determine for yourself if graduate school is the best way to get where you want to go. There is an opportunity cost associated with graduate school, and it's important to look at your options to make an informed decision. If you are unable to commit to a PhD it might be possible to still build technical skills by other means, such as free online courses, seminars, weekend coding camps, blogging, etc.

\section{Do you have any advice for current graduate students who would like to envisage a similar career-path?}

My advice would be to take the time to learn outside of traditional academia. Your resume talks about your academic skills, but in business it helps to build a portfolio of your actual work. This portfolio should demonstrate that you have initiative, and show things you have done in areas of interest outside of your research. In my case, I had no formal business training, but I was passionate 


\section{HealTh SCience Inquiry}

about innovation and entrepreneurship. I took advantage of opportunities to attend courses and seminars on these subjects, and I put the knowledge to practical use in my ongoing journey of developing a clinical device.

However, your portfolio pieces don't have to be successes, and can be anything that demonstrates your interest, initiative, and commitment. As an example, you might have written a blog post about biotechnology and conducted research into a particular company to evaluate their product's novelty in the market. The subject material doesn't even have to be related directly to your research. If there is some aspect of business you are passionate about, there is no reason you can't build a body of knowledge in that on your own time. It may not be the same quality as a professional market report, but it still shows that you put yourself out there and people will credit you for making the attempt.

People are looking for what makes you different from other candidates, so you've got to give yourself an edge. 